\title{
木摺漆喰天井における漆喰の喰 いつきに関する研究
}

\section{A STUDY ON THE ADHESION OF PLASTER IN LATH AND PLASTER CEILING}

\section{津和佑子- $* 1$ 今井琢也 $-* 2$
藤本貴之一 - - $* 3$ \\ 腰原幹雄— $* 5$ \\ キーワード : \\ 木摺漆喰, 天井, 付着力, 近代建築, 歴史的建造物, 複合材料}

Keywords:

Lath and plaster, Ceiling, Adhesion, Modern Japanese style architecture, Historic buildings, Composite materials

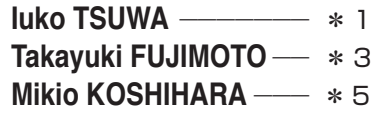

Takuya IMAI $-* 2$

We conducted tension and shearing tests on lath and plaster ceiling in order to reveal the structural mechanism about the adhesion of plaster to wooden laths. In addition, we developed a mechanical model and a structural design formula for lath and plaster ceiling. Through the tests, it was found that whether plaster is pushed out to the rear of wooden laths or not, has the most important influence on the adhesion of plaster. We could develop the formula to accurately evaluate the strength of lath and plaster ceiling.

\section{1. はじめに}

非構造部材である天井部材の落下被害が生じたことから一般建築 における天井の落下防止措置に関して新たな基準が設けられ，吊天 井などの構造性能の検証等が実施されるようになってきた。文化財 建造物においても洋館等で用いられる漆喰天井の漆喰が脱落する被 害が見られ，天井材落下の対策が問題になっている ${ }^{1)}$ 。

本研究で扱う木摺漆喰天井とは木摺を下地として, 木摺をある一 定間隔に並べ，木摺と木摺の間に漆喰を食い込ませて作られる天井 工法の一種である。木摺の裏側にはみ出した漆喰がたれて引っかか りができることで，木摺と漆喰を一体化させていると言われている (図 1)。このように漆喰と木摺が一体となることを, 日本の左官職 人の間では漆喰の「喰いつき」と呼んでおり，本研究でもそれにな らうこととする。

漆喰が落下する被害を確認すると, 漆喰が木摺との界面で剥離し ているものや, 木摺間の漆喰ごと抜け落ちているものが見られる ${ }^{1)} 。$ 漆喰が脱落する際の抵抗力としては上記の漆喰の喰いつきが考えら れ，その要因として木摺背部への漆喰のはみ出しによる引っ掛かり や，漆喰と木摺との付着などが挙げられる。しかし各々の要因がど のように喰いつきに作用しているかは明らかになっていない。そこ で, 本研究では漆喰の喰いつきの構造性能を把握することを目的と した基礎的な実験を実施する。その後，実験結果に基づき，木摺漆 喰天井における漆喰の喰いつきの力学的モデルを構築し, 設計への 適用を念頭に置いた最大耐力の算定式を提案する。

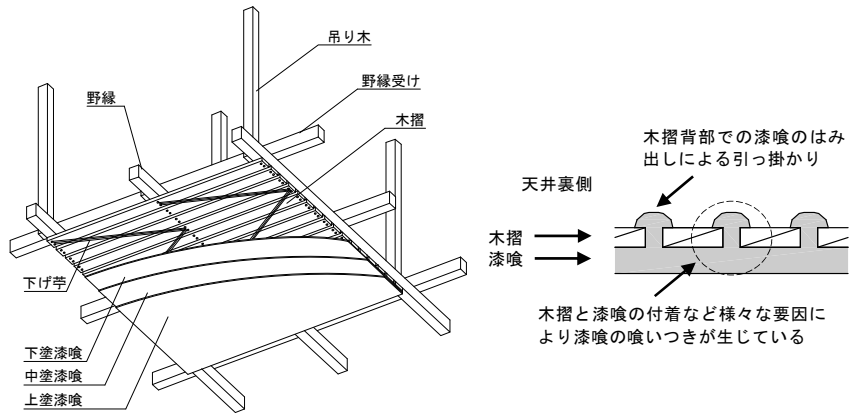

図 1 木摺漆喰天井と篍喰の喰いつき

\section{2. 実験方法}

\section{1 実験概要}

実験は鉛直方向とせん断方向に対する喰いつきの構造性能を把握 するために, 引張試験とせん断試験を実施した。引張試験について は全面引張試験と部分引張試験の 2 種類とした。前者は試験体の全 面を加力し, 後者は試験体の一部を加力し, 加力面の周囲の漆喰が 加力面にどのように引きつられるか，その影響範囲を確認した。

\section{2 試験体}

試験体は表 2 に示すように, 木摺背部一の漆喰の喰いつきの形状, 木摺の間隔, 木摺の形状, 補強材の種類をパラメータとし, 10 種類 とした。試験体作製の工程は大きく分けて下塗り, 中塗り, 上塗り の 3 工程とした。作製方法は，喰いつきに影響する下塗りの工程の み実際の天井と同じ施工状況をつくり上向きで施工し, 中塗りと上 塗りは下向きで施工した。試験体は約 $1 \mathrm{~m}$ 角の木摺漆喰天井面を作成

\footnotetext{
The Japanese Association for Conservation of Architectural Monuments, Dr. Eng.

Graduate Student, Graduate School of Engineering, The Univ. of Tokyo

Structural Design Office OAK, M. Eng

4 The Japanese Association for Conservation of Architectural Monuments

5 Prof., Institute of Industrial Science, The Univ. of Tokyo, Dr. Eng.
}

（公財）文化財建造物保存技術協会 博士（工学）

（产116-0013 東京都荒川区西日暮里 2-32-15)

東京大学大学院工学系研究科 修士課程

(株オーク構造設計 修士（工学）

（公財）文化財建造物保存技術協会

東京大学生産技術研究所 教授・博士（工学） 
し，そこから $30 \mathrm{~cm}$ 角のものを 4 体採取した。このうち 3 体は全面 引張試験あるいはせん断試験に, 残りの 1 体は中央 $10 \mathrm{~cm}$ 角を加力 面とした部分引張試験に使用した。漆喰の塗厚は $15 \mathrm{~mm}$ とし, 下げ艼 は $30 \mathrm{~cm}$ 角の試験体に $V$ 字型が 1 本全面に入るように配置した。た だし, 部分引張試験には下げ苧を配置していない（図 2)。補強材の 詳細な仕様は表 2 中に示す。No. 8,9 に使用したネットは約 $1 \mathrm{~m}$ 角の 全面に下塗りの段階で木摺に釘留めはせず伏せこんだ。ネットの種 類は左官で近年よく使用される材料を用いた。

\section{3 加力方法}

加力方法を図 2 に示す。全面引張試験とせん断試験については, 漆喰面に $30 \mathrm{~cm}$ 角の鉄板をエポキシ樹脂系接着剤によって接着し， 鉄板に加力治具を取り付け加力した。部分引張試験については $10 \mathrm{~cm}$ 角の鉄板を $30 \mathrm{~cm}$ 角の漆喰面の中央に接着し, 鉄板中央に加力治具 を取り付け加力した。引張試験では試験体を実際の天井の向きとは 上下を逆に設置し加力し，せん断試験では試験体を垂直に設置し加 力している。

\section{3. 実験結果}

各試験体の破壊後の様子を図 3 に，落下防止を考慮して最大耐力 を図 4 に示す。実験には鉄板の接着面で剥がれて加力を終了したも のと，鉄板が接着面で外れたため，鉄板を貼り直し再加力したもの がある。これらの結果については表 2 に示す通り名前を区別して表 記する。なお No. 3-2a, b, c, d の試験体は，加力前に木摺面から漆喰 が剥離したため，加力を行っていない。

\section{1 全面引張試験}

図 3（i ），(ii），（iii）より全面引張試験では木摺間の下塗り部 分での剥離と中塗り部分での剥離，木摺間の漆喰の抜け出しが見ら れた。漆喰の木摺背部への喰いつき方を変えた No. 1， No. 2， No. 3 の最大耐力を比較すると, 最大耐力の平均值は No. 1 に比心゙No. 2 は 約 $1 / 4$ となった。このことより漆喰が木摺の背部へはみ出し，漆喰 が木摺に引っかかるか否かが最大耐力に最も影響を与えるというこ とが読み取れる。また No. 2, No. 3 を比較すると，耐力に大きな差が 見られないことから，木摺間における木摺と漆喰の付着力はほとん どないことも判明した。No. 1 に対して, 補強材を変更したもの (No. 7, No. 8，No. 9，No. 10）を比較すると，必ずしも補強材を変更したもの の最大耐力が大きいわけではないことがわかる。木摺の形状を変え た No. 6 の最大耐力はN No. 2 よりも平均して約 4 倍大きくなった。こ れは木摺の形を台形にしたことで，木摺間の漆喰と木摺の付着だけ でなく，漆喰の木摺への引っ掛かりが生じたためと考えられる。た だし，漆喰を施工寸る際，台形の木摺では塗った漆喰が木摺間から 垂れや寸く，施工性が良いとは言えないことが課題である。

試験体の漆喰の密度は $1.3 \mathrm{~g} / \mathrm{cm}^{3}$ であったため, $30 \mathrm{~cm}$ 角, 厚さ $15 \mathrm{~mm}$ の試験体の漆喰重量は 0.017kN である。No. 1 の最大耐力（a, b, c の 平均值 $1.74 \mathrm{kN}$ ）は, 漆喰の自重の約 100 倍であった。最大耐力が最 も低い No. 2（a,b,c の平均值 $0.05 \mathrm{kN}$ ） も自重の約 3 倍の耐力を保持 していた。このことより木摺漆喰天井は劣化等がなければ自重に対 しては十分な耐力を有していると言える。

\section{2 部分引張試験}

部分引張試験では No. 2-1d, No. 3 を除くと,ほぼ加力面のみの漆喰 が中塗りで剥離し, 加力した $10 \mathrm{~cm}$ 角の周囲の漆喰には大きな損傷

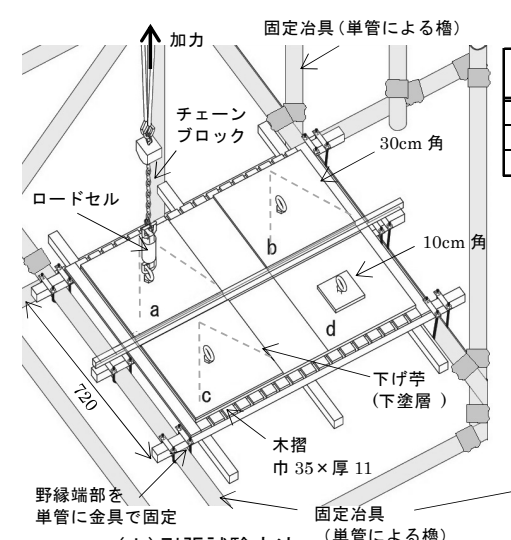

(i )引張試験方法 (単管による橹)

\section{図 2 試験体と加力方法}

\begin{tabular}{|c|c|c|}
\hline & 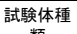 & 試験体個数 \\
\hline 試験产 & 類 & $\begin{array}{l}\text { (個/種類) } \\
\end{array}$ \\
\hline 全面引張試験 & 10 & 3 \\
\hline 部分引張試験 & 10 & 2 \\
\hline せん断試験 & 10 & 3 \\
\hline
\end{tabular}

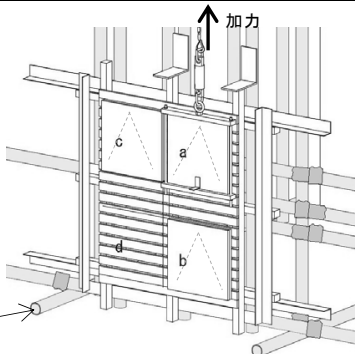

ii ) せん断試験方法

表 2 試験体一覧

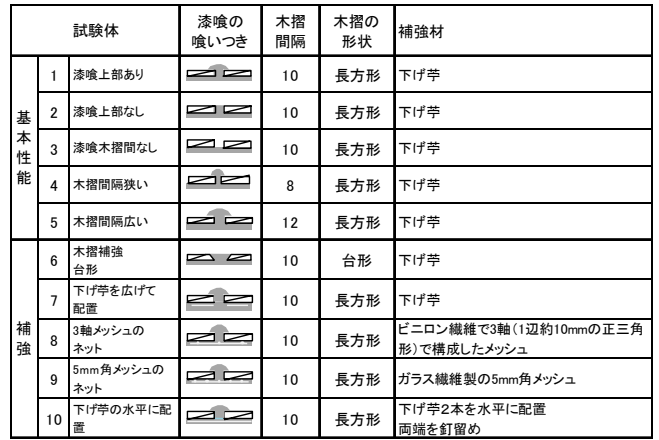

試験体番号は，試験体種類番号の後に-1a,-1b,-1c を全面引張試験

$2 \mathrm{a},-2 \mathrm{~b},-2 \mathrm{c}$ をせん断試験, $-1 \mathrm{~d},-2 \mathrm{~d}$ を部分引張試験とする。

鉄板の接着面で剥がれて加力を終了したものは末尾に*を、加力中に

鉄板が接着面で外れ鉄板を貼り直し再加カしたものは末尾に**をつける。

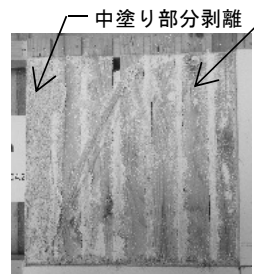

下塗り部分剥離

木摺間の漆喰の抜け出し

（i ）1-1a, 全面引張試験（ii ) 1-1b, 全面引張試験
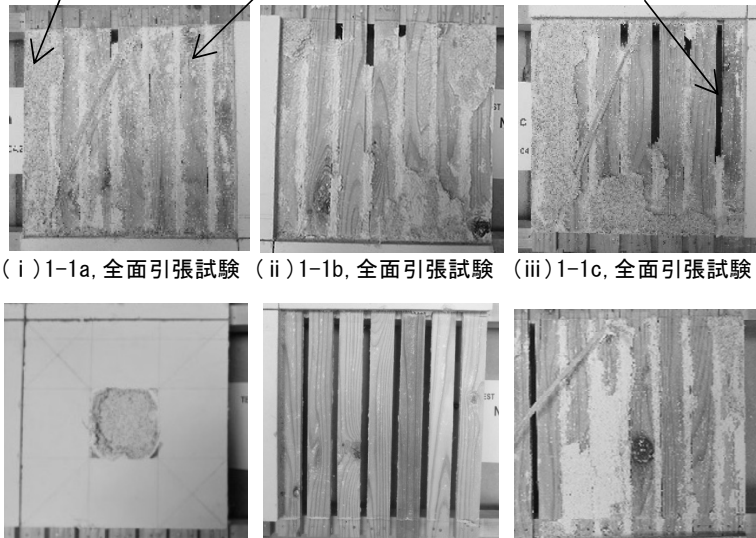

(iii) $1-1 \mathrm{c}$, 全面引張試験

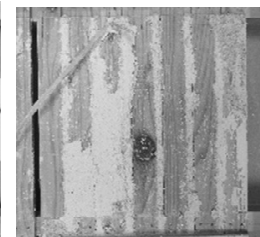

部分引張試（vi）1-2b, せん断試験

図 3 破壊後の試験体
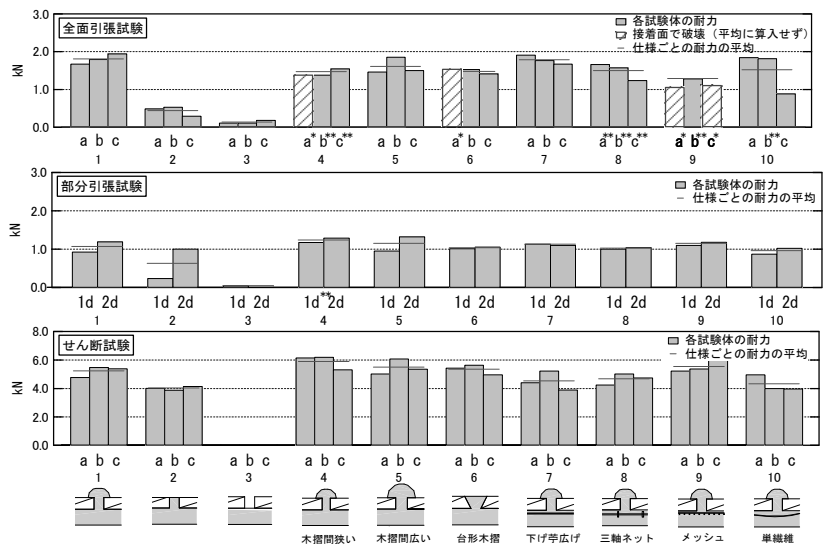

図 4 試験結果 
は見られなかった（図 3 (iv))。一方, No.2-1d, No. 3 では加力面の 周囲の漆喰も含め試験体全体が剥離した（図 3（v))。これは, 漆 喰が $30 \mathrm{~cm}$ 角内の木摺背部に十分にはみ出し引っ掛かりがある場合, その引っ掛かりによる引張抵抗力が $10 \mathrm{~cm}$ 角内の漆喰中塗層の付着 力よりも強いためであると考えられる。その結果, 漆喰中塗層が破 壊し, 漆喰が剥離したと考えられる。最大耐力は, No. 2-1d, No. 3 以外は, いずれも最大耐力が約 $1 \mathrm{kN}$ となった。

\section{3 せん断試験}

図 3 （vi）のようにNo. 3 を除く全ての試験体で木摺と漆喰の界 面, つまり木摺間にある下塗り漆喰で破壊が生じた。

試験体の仕様ごとの最大耐力の平均值について No. 1 を基準にす ると他の試験体は約 0.8 倍から約 1.2 倍の值を示している。漆喰の 喰いつきの形状や木摺の形状は最大耐力に多少の影響は与えるもの の, 全面引張試験と比べると破壊性状も含めて大きな違いは見られ なかった。

\section{4. 力学的モデル}

\section{1 バネの配置}

実験結果に基づき，力学的モデルを構築する。まず試験体の破壊 状況より, 木摺漆喰の破壊モードを引張試験では面状破壊・線状破 壊・抜け出し破壊の 3 つに, せん断試験では面状破壊・線状破壞の 2 つに分類した（図 5)。そしてこれらの破壊モードを組み合わせる ことで, すべての試験体は 4 種類の破壊性状に分類することができ る（表 3, 表 4)。また破壊形式と木擢漆喰の構造を考慮し，木摺漆 喰の外力に抵抗するバネを図 6 のように配置した。

\section{2 特性値の算出}

以下の 3 つの仮定を行うことで, 各バネの特性值（最大応力度） を算出する。

1. 全ての試験体は 3 種類の破壊モードの組み合わせ, あるいは単一 のモードで破壊している。

2. 最大耐力時にその破壊モードに関与するバネは全て最大応力度を とっている。

3. 面としての最大引張応力度 ${ }_{\mathrm{a}} \sigma_{\text {max }}$ は全面引張試験と部分引張試験 より推定可能であるが，部分引張試験は面状破壊の単一モードのみ で破壊しており全面試験結果と破壊性状が異なるため，ここでは区 別する。なお部分引張試験より求められたバネ $\mathrm{a}$ の特性值を ${ }_{\mathrm{a} 1} \sigma_{\text {max }}$, 全面引張試験より求められたものを ${ }_{\mathrm{a} 2} \sigma_{\max }$ とした。

上記の仮定を踏まえ, 各特性值を算出する。まず表 3 , 表 4 に示 すように単一のバネにより試験体の耐力が決まるものから特性值を 求める。次に複数のバネにより耐力が決まるものについて, それぞ れの破壊モードの面積を図 5 のような試験体の破壊後の写真画像か ら算出する。それぞれの面積に既に求めたバネの特性值を掛けて耐 力を算出し, 全体の耐力から差し引くことで残りのバネの耐力を求 め, 特性值を算出する。表 5 に求めた特性值の平均值を示す。ただ し木摺からのはみ出しによる漆喰せん断バネ e の特性值 $\sigma_{\mathrm{e}} \sigma_{\max }$ につ いては, は夕出しの形状が逐一変化するため, 抜け出し長さあたり の抵抗力 $\mathrm{e}_{\max }$ も共に記す。

\section{5. 設計への適用}

\section{1 引張力とせん断カに対する耐力算定式}
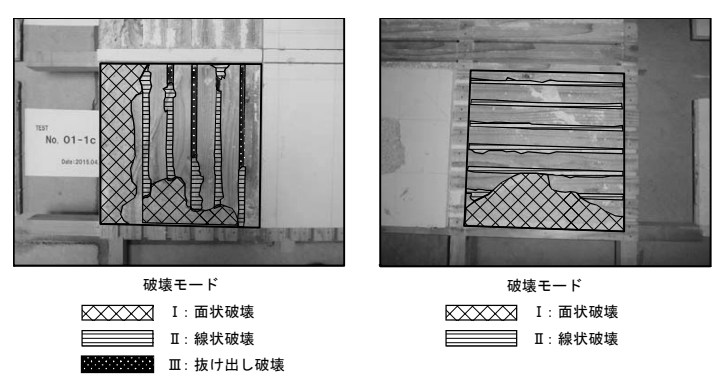

ए 1 : 面状破填 全面引張試験

全面せん断試験

図 5 試験体の破壊モード
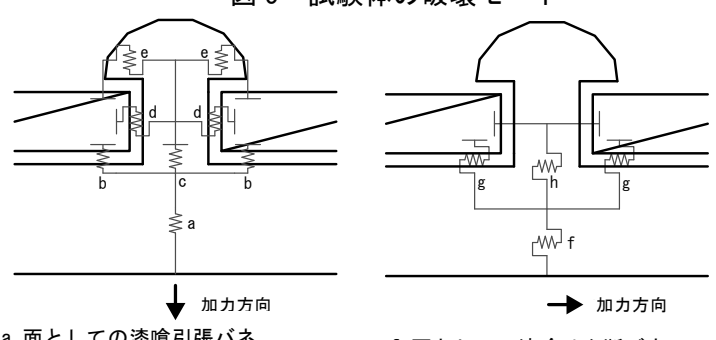

a. 面として坏と淡的

c. 木摺間の線としての溙喰引張バネ

c. 木摺間の線としての漆喰引張バネ
d. 木摺と䬩の付着せん断バネ

e. 木摺からのはみ出しによる㴚喰せん断バネ

図 6 木摺渌喰の外力に対する抵抗要素

表 3 破壊モードと抵抗バネの関係（全面引張試験）

\begin{tabular}{|c|c|c|c|c|c|c|c|c|c|c|}
\hline \multirow{2}{*}{\multicolumn{5}{|c|}{ 破䧇モードの組み合わせ }} & \multicolumn{5}{|c|}{ 抵抗バネ } & \multirow[b]{2}{*}{ 備考 } \\
\hline & & & & & $\mathrm{a}$ & $\mathrm{b}$ & $\mathrm{c}$ & d & $\mathrm{e}$ & \\
\hline & & & & 抜け出し破壊 & - & $\begin{array}{l}\mathrm{O} \\
\mathrm{O}\end{array}$ & - & 0 & - & $\begin{array}{l}\text { No. 3-1より } \\
\text { No. 2-1より }\end{array}$ \\
\hline $\begin{array}{l}\text { 線状破壊 } \\
\end{array}$ & & & & & - & 0 & $\mathrm{O}$ & - & - & - \\
\hline $\begin{array}{l}\text { 線状破壊 } \\
\end{array}$ & + & 面状破溒 & + & 掎け出，破搷 & $\mathrm{O}$ & $\frac{0}{0}$ & $\frac{0}{0}$ & - & - & - \\
\hline
\end{tabular}

表 4 破壊モードと抵抗バネの関係（せん断試験）

\begin{tabular}{|c|c|c|c|c|c|c|c|}
\hline \multirow{2}{*}{\multicolumn{4}{|c|}{ 破壊モードの組み合わせ }} & \multicolumn{3}{|c|}{ 抵抗バネ } & \multirow{3}{*}{$\begin{array}{c}\text { 備考 } \\
\text { No. 3-2より* }\end{array}$} \\
\hline & & & & $f$ & $\mathrm{~g}$ & $\mathrm{~h}$ & \\
\hline 綿状破烓 & & & 报け出し破壊 & - & 0 & - & \\
\hline 線状破壊 & + & 面状破填 & & 0 & 0 & 0 & - \\
\hline
\end{tabular}

表 5 特性値一覧

\begin{tabular}{|c|c|c|c|c|c|c|c|c|c|c|}
\hline バネ名称 & & & b & c & $\mathrm{d}$ & & & $f$ & $\mathrm{~g}$ & $\mathrm{~h}$ \\
\hline 特性値 & $\begin{array}{c}\text { a1 } \sigma_{\max }\left(\mathrm{N} / \mathrm{mm}^{2}\right) \\
\text { ( })\end{array}$ & $\begin{array}{l}\text { a2 } \sigma_{\max } \\
\left(\mathrm{N} / \mathrm{mm}^{2}\right)\end{array}$ & $\begin{array}{l}{ }^{b} \sigma_{\max } \\
\left(\mathrm{N} / \mathrm{mm}^{2}\right)\end{array}$ & $\begin{array}{l}{ }_{0} \sigma_{\max } \\
\left(\mathrm{N} / \mathrm{mm}^{2}\right)\end{array}$ & $\begin{array}{l}{ }_{\mathrm{d}} \tau_{\max } \\
\left(\mathrm{N} / \mathrm{mm}^{2}\right)\end{array}$ & $\begin{array}{l}e^{Q_{\max }} \\
(\mathrm{N} / \mathrm{mm})\end{array}$ & $\begin{array}{l}\mathrm{e}^{\sigma_{\max }} \\
\left(\mathrm{N} / \mathrm{mm}^{2}\right)\end{array}$ & $\begin{array}{l}\text { fo } \tau_{\max } \\
\left(\mathbb{N} / \mathrm{mm}^{2}\right)\end{array}$ & $\begin{array}{l}{ }_{\mathrm{g}} \tau_{\max } \\
\left(\mathrm{N} / \mathrm{mm}^{2}\right)\end{array}$ & $\begin{array}{l}\mathrm{h} \tau_{\max } \\
\left(\mathrm{N} / \mathrm{mm}^{2}\right)\end{array}$ \\
\hline 平均 & 0.096 & 0.021 & 0.0007 & 0.0587 & 0.0082 & 1.15 & 0.208 & 0.127 & 0.000 & 0.198 \\
\hline
\end{tabular}

前章で求めた各特性值を使用して新たに木摺漆喰を施工する際に, その耐力を予測する算定式を考案する。図 5 で示した 3 つの破壊モ ード（面状破壞, 線状破壊, 抜け出し破壞）は, どのバネが最大耐 力に対して支配的であるかによって図 7 , 図 8 の様に分類できる。 それらの分類に基づき, 設計值は次の手順で求める事ができる。 まずそれぞれの特性值にそれに対応する面積を掛けあわせ, 試験体 がそのバネで破壞した時の耐力を予測する（例えばバネ $\mathrm{b}$ の場合, ${ }_{b} \sigma_{\text {max }} \times$ 木摺の面積)。次に同じ破壊モードのうち最も高い耐力を示 寸特性值をそのモードの耐力とする（例えば線状破壊の場合, バネ $\mathrm{b}$ とバネ $\mathrm{c}$ で破壞した時の耐力のうち大きい值)。最後に各破壊モー ドの耐力のうち, 最も低い值を試験体の設計值とする(式 (1), (2))。 引張力に対する設計值 $=\min \{A, \max \{B, C\}, \max \{B, D, E\}\}$ 式 (1) せん断力に対する設計值 $=\min \{F, \max \{G, H\}\}$ 式 (2) ただし大文字の英字は各バネの耐力を示し，(特性值）×（それに対 応する面積または長さ）によって求められる。

\section{2 耐力算定式の評価}

考案した算定式（式（1），（2））の妥当性を評価する。図 9 に 
各試験体の設計值を実験值で除した検定值を示している。検定值は 試験結果を算定式で求めた值で除したもので，1 以下の時に安全側 の設計と言える。図 9 よりほぼ全て試験体に関して, 検定值が 1 以 下であることから, 考案した算定式で安全側に設計できることを示 した。

ほぼ全ての試験体に関して検定值が 1 を下回り安全率が生じる理 由には次の 2 点が考えられる。1 点目は実際に試験体が破壞した時 に漆喰が抵抗していた幅と, 設計值を算出する際に想定していた漆 喰が抵抗する幅が異なるためである。例えば全面引張試験で線状破 壊の耐力がバネ $\mathrm{c}$ で決まる時を考えてみると, 設計值はバネ $\mathrm{c}$ の特 性值 $\sigma_{\text {max }}$ に木摺間の漆喰の幅をかけることで求められる。しかし 実際には木摺間の漆喰は周囲を引き連れて破壊するため, 設計值を 算出するときに想定した幅よりも実際に壊れる時の漆喰の幅は大き くなり耐力が上昇する（図 10）。2 点目は設計值を求める際に単一 のモードのみで破壊すると想定しているためである。実際の破壞性 状は図 5 のように, いくつかの破壊モードが混在して破壊する。し かし本算定式は最も低い耐力の破壊モードでのみ破壊する仮定して いるため, 実際の耐力より低く評価することになる。一方, 検定 值が 1 を上回る試験体がいくつかあるが，これは漆喰という材料自

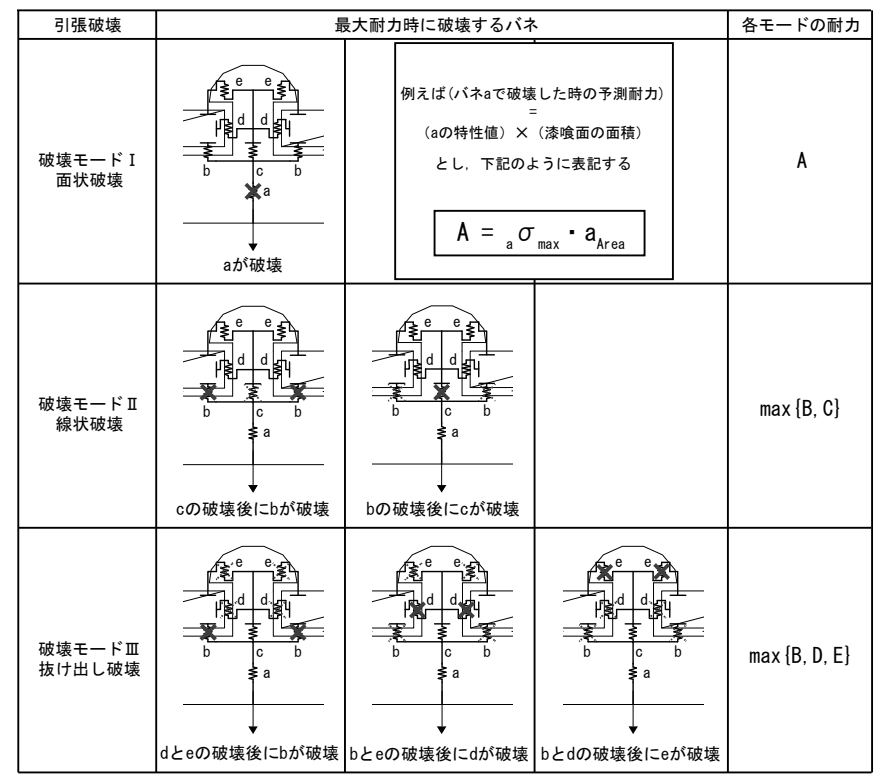

引張力に対する設計値 $=\min \{A, \max \{B, C\}, \max \{B, D, E\}\}$

図 7 引張加力時の破壊モード別の耐力と算定式

\begin{tabular}{|c|c|c|c|}
\hline せん断破壊 & 最大 & 破壊するバネ & 各モードの耐力 \\
\hline $\begin{array}{c}\text { 破壊モード I } \\
\text { 面状破壊 }\end{array}$ & 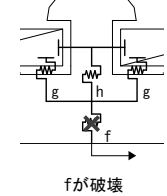 & 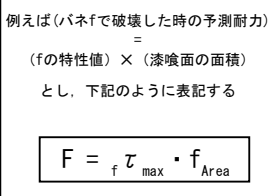 & $\mathrm{F}$ \\
\hline $\begin{array}{l}\text { 破罣モードII } \\
\text { 線状破壊 }\end{array}$ & 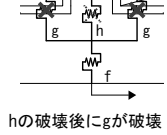 & $\underset{\mathrm{g} \text { の破壊後にんが破壊 }}{\stackrel{\mathrm{m}}{\mathrm{m}}}$ & $\max \{\mathrm{G}, \mathrm{H}\}$ \\
\hline
\end{tabular}

せん断カに対する設計値 $=\min \{\mathrm{F}, \max \{\mathrm{G}, \mathrm{H}\}\}$ 図 8 せん断加力時の破壊モード別の耐力と算定式
体の構造性能にばらつきが生じるためである。今後試験体数を増や すことで解消寸る事ができると考えられる。

\section{6. まとめ}

木摺漆喰天井の漆喰の喰いつきに着目し, 木摺漆喰天井の全面引 張試験, 部分引張試験, せん断試験を行った。本実験により得られ た知見は以下の通りである。

1 ）全面引張試験では木摺間の漆喰の有無や木摺の背部に漆喰がは み出しているかどうかが最大耐力に大きな影響を与える。

2 ）部分引張試験では全面引張試験と同様に 1 ）に示寸傾向が見ら れた。また，ほとんどの試験体で加力面でのみ破壊が生じた。

3 ）せん断試験では木摺間の漆喰や木摺背部へのはみ出しがない No. 3 を除くと, 全ての試験体が同程度の最大耐力を示した。

$4 ）$ 補強材を追加した試験体（No.7～10）では, 従来の工法である 試験体（No. 1）と比べ, 最大耐力の向上は見られなかった。

5 ）木摺漆喰天井の喰いつきの力学的モデルを引張バネ及びせん断 バネで作成し, 実験結果から各バネの特性值を算出することがで きた。ただし特性值は試験体の仕様によって変わることが考えら れ, 漆喰の材料特性や経年変化などの影響については別途検討が 必要である。

6 ）提案した算定式 (1)，（2）を用いることで, 今回実験した木 摺漆喰天井の耐力を評価することができた。

7 ) 本検討では漆喰の喰いつきについて基礎的な構造性能を把握で きたが, 今後, 実際の建物での脱落状況と併せたモデル化や既存 天井の構造性能評価方法の検証を進める必要がある。

本実験を行うにあたり多大な御協力を頂いた関係者各位に心から 謝意を表します。

\section{参考文献}

1) 岩田昌之, 津和佑子:天井部材の構造安全性について,『文建協通信』No. 121, P. $34-41,2015.7$

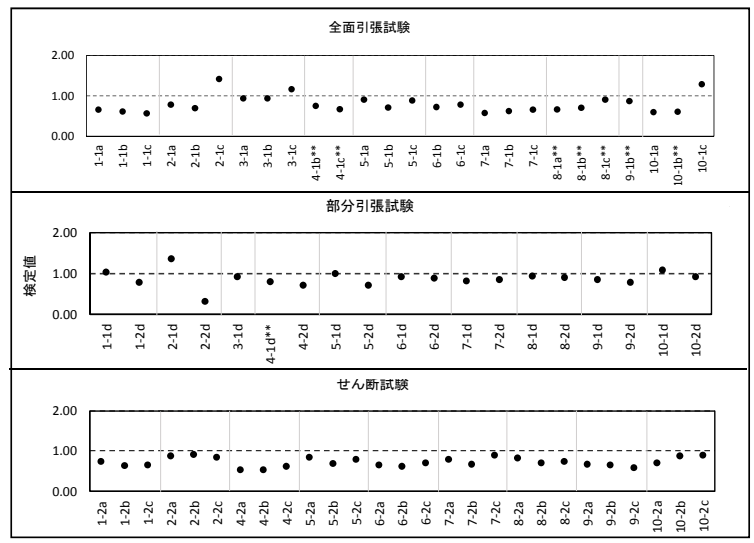

図 9 各試験体の検定值

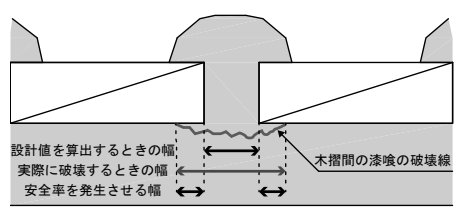

図 10 実際に破壊する時の幅と設計值算出時の幅

[2016 年 10 月 5 日原稿受理 2016 年 12 月 9 日採用決定］ 